\title{
ON-LINE AUDIT
}

\section{STANCIU, V[lad] - V[iorel]; BARBU, C[ostel] \& BARBU, N[icoleta]}

\begin{abstract}
The audit appeared as a consequence of the requirements to have an objective assessment of how management operates. If initially it was strictly applied in finance, it proved effective in other non-financial areas, such as security, IT systems performance or environmental aspects. IT infrastructure has infiltrated all branches of economic processes. IT Infrastructure audit is a demand for significant improvement of business process performance. In this paper I have tried to draw attention to the increasing importance of online audit, during last years.

Keywords: online audit, audit continuous audit, IT system, database
\end{abstract}

\section{INTRODUCTION}

Auditors' role within a company is more and more significant, considering the contribution they have into the decision-making process.

The auditor assesses the controls implemented by managers and issues a report. If the manager has to ensure the controls are applied, an auditor shall provide a guarantee of the manner of controls application, their effectiveness and the purpose they have been defined for.

Traditional auditing (both internal and external) has changed considerably in recent years, primarily as a result of changes in the data processing environment.[Roussey, 1986 ; Elliot, 1986; Vasarhelyi and Lin, 1988; Bailey et al., 1989].

These changes have created major challenges in performing the auditing and attestation function. These changes and the technical obstacles created for auditors as a result of these changes are summarized in Tab. 1.

\begin{tabular}{|c|c|c|c|c|}
\hline Phase & Period & $\begin{array}{c}\text { Data } \\
\text { Processing } \\
\text { of Functions }\end{array}$ & Applications & Audit Problem \\
\hline 1 & $1945-195$ & $\begin{array}{c}\text { Input (I) } \\
\text { Output (O) } \\
\text { Processing (P) }\end{array}$ & $\begin{array}{c}\text { Scientific \& } \\
\text { Military } \\
\text { applications }\end{array}$ & $\begin{array}{c}\text { Data } \\
\text { transcription } \\
\text { Repetitive } \\
\text { processing }\end{array}$ \\
\hline 2 & $\begin{array}{c}1955- \\
1965\end{array}$ & $\begin{array}{c}\text { I, O, P } \\
\text { Storage (S) }\end{array}$ & $\begin{array}{c}\text { Magnetic tapes } \\
\text { Natural } \\
\text { applications } \\
\text { visually } \\
\text { readable }\end{array}$ & $\begin{array}{c}\text { Data that may } \\
\text { be changed } \\
\text { without traces }\end{array}$ \\
\hline 3 & $1965-$ & $\begin{array}{c}\text { I, O, P, S } \\
\text { Communicatio } \\
n\end{array}$ & $\begin{array}{c}\text { Time-sharing } \\
\text { systems } \\
\text { Disk storage } \\
\text { Expanded } \\
\text { Operations } \\
\text { support }\end{array}$ & $\begin{array}{c}\text { Access to data } \\
\text { without } \\
\text { physical access }\end{array}$ \\
\hline 4 & 1975 & $\begin{array}{c}\text { Integrated } \\
\text { databases } \\
\text { Decision } \\
\text { Support }\end{array}$ & $\begin{array}{c}\text { Different } \\
\text { physical and } \\
\text { logical data } \\
\text { layouts }\end{array}$ \\
\hline
\end{tabular}

\begin{tabular}{|c|c|c|c|c|}
\hline & & & $\begin{array}{c}\text { Systems } \\
\text { (decision } \\
\text { aides) } \\
\text { Across-area } \\
\text { applications }\end{array}$ & $\begin{array}{c}\text { New } \\
\text { complexity } \\
\text { layer (DBMS) }\end{array}$ \\
\hline 5 & $\begin{array}{c}1986- \\
1991\end{array}$ & $\mid \begin{array}{c}\text { I, O, P, S, C, D } \\
\text { Workstations } \\
\text { (W) }\end{array}$ & $\begin{array}{l}\text { Networks } \\
\text { Decision } \\
\text { support } \\
\text { systems (non- } \\
\text { expert) } \\
\text { Mass optical } \\
\text { storage }\end{array}$ & $\begin{array}{c}\text { Data } \\
\text { distributed } \\
\text { among sites } \\
\text { Large } \\
\text { quantities of } \\
\text { data } \\
\text { Distributed } \\
\text { processing } \\
\text { entities } \\
\text { Paperless data } \\
\text { sources } \\
\text { Interconnected } \\
\text { systems } \\
\end{array}$ \\
\hline 6 & 1991-on & \begin{tabular}{|c|}
$\mathrm{I}, \mathrm{O}, \mathrm{P}, \mathrm{S}, \mathrm{C}$ \\
$\mathrm{D}$, \\
$\mathrm{W}$ \\
Decisions (De) \\
\end{tabular} & $\begin{array}{c}\text { Decision } \\
\text { support } \\
\text { systems (expert) }\end{array}$ & $\begin{array}{c}\text { Stochastic } \\
\text { decisions } \\
\text { impounded into } \\
\text { MIS }\end{array}$ \\
\hline
\end{tabular}

Tab. 1. The Evolution of Auditing from a Data Processing Perspective

The existence of local, regional or national databases, public or accessible in certain conditions, will facilitate the introduction of new approaches on specific information processing, including for auditing. The main qualitative predictable change compared with traditional audit is the possibility of checking online the database located at distance and, thus, performing a significant part of the audit without requiring physical presence (movement) at the audited entity.

Essential conditions for on-line audit are Internet access and compatibility of IT tools used by the auditor and audited entity, including the assurance of data transfer speed and quality. Online audit consists of collecting information about the audited entity, from publicly accessible databases, as well as analysis of documentation, statements, and explanations provided in electronic format.

\section{NEW APPROACHES OF AUDIT: ONLINE AUDIT AND CONTINUOUS AUDIT}

The central issue of IT systems audit systems in general and of online audit, in particular, is creating a framework to provide comprehensive and complete data, applications, high-level IT tools, able to facilitate access to auditees data, under protection of security and integrity of information and meet legal requirements, regulatory and executive for IT audit.

In the context of the extension of e-governance systems and applications, adequate infrastructure for eaudit systems will be provided, which will allow the globalization of information exchange, popularization of 
IT applications, standardization of the procedures, optimal access to information in safe conditions. This evolution is supported, technically, by specific infrastructure development (Fig. 1).

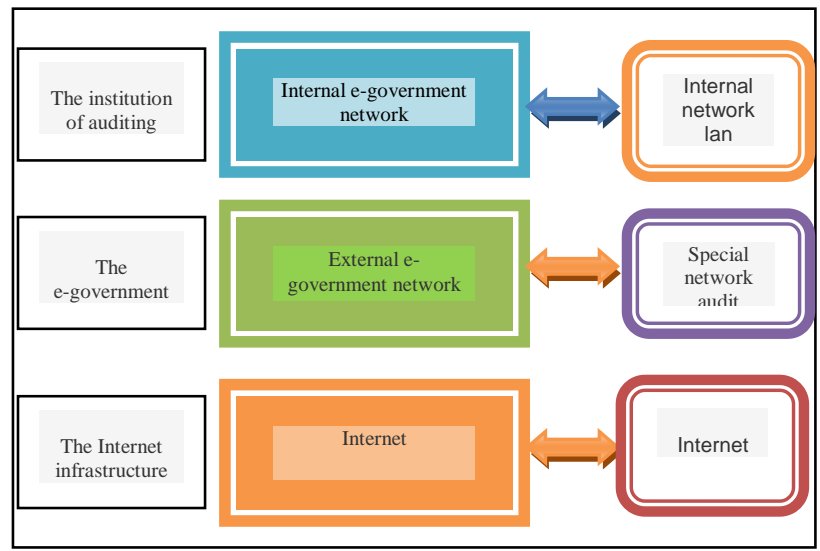

Fig. 2. Infrastructure support for on-line audit

Implementation of computer-based or computerassisted audit is a very important stage, which can automate integral or partly a series of activities including: project management, data collection, compilation of statistics, development of sampling, evaluation and testing procedures, preparation of working documents (models, questionnaires, checklists), audit report development, analysis.

Online audit is a modern auditing method, which provides access to the auditor regarding the audited entity (or its administrative network) so that it can directly capture information in a computer networks based environment (Internet, intranet) .

Implementation of online audit techniques proves very useful in the audit preparation stage, as well as in post audit documentation development in electronic format.

Audit quality is decisively influenced by several factors such as:

- Audit standardization ;

- Database quality ;

- Application interconnections ;

- Auditors training, etc.

A major tool in conducting on-line audit is provided by the document management system. Electronic documentation of the audit allows a better determination of the circumstances, representing a basis for the audited entity assessment in terms of legal criteria. Processed information security is one of the most difficult elements of online audit, which involves data transfer, collection and recording. Data protection system must ensure security of information acquired during the audit, these being audit confidential.

From a number of requirements related to audits frequency increase, the situation has evolved to a refined form of online audit, continuous audit, which involves continuous interaction between the auditor with audited entity system, thus perfecting the access to information content and its presentation in due time.

In continuous auditing process, data flow through the system is monitored and analyzed continuously (e.g., daily) using a set of auditor defined rules. Exceptions to these rules will trigger alarms which are intended to call the auditor's attention to any alterations or anomalies in the system. Continuous auditing process amounts to an analytical review technique since constantly analyzing a system allows the auditor to improve the focus and scope of the audit.

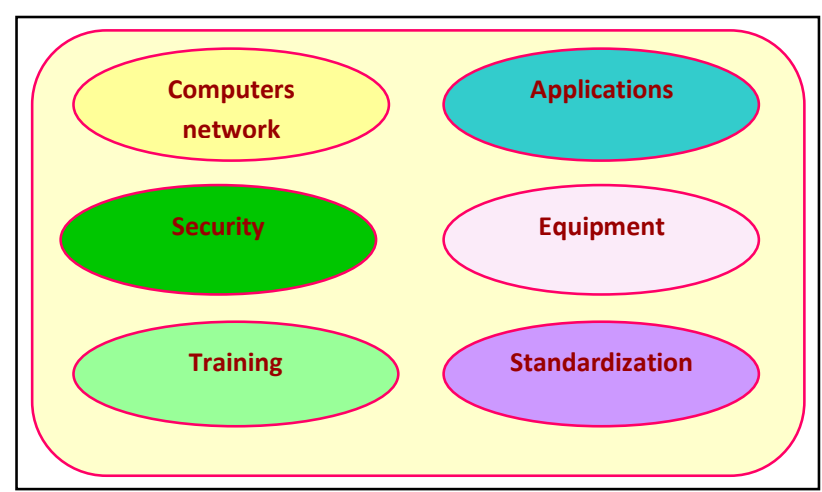

Fig. 2. Components of an online audit platform

Audit through databases is a natural choice that is necessary because relational database technology is the essential common trigger for enterprise information systems, regional or national databases (statistical, financial, population, etc.). In the actual stage, given the fact that, nationally, there is a variety of databases, some belonging to obsolete platforms, the issue of developing custom applications that process information from heterogeneous data sources has been raised.

Generally speaking, integrated online audit faces a variety of systems with low communication facilities and security issues associated risks. Development of appropriate audit procedures is not an easy task and it is strongly conditioned on the existence of common coding scheme (preferably unique), and on the availability of high-level standardization.

\section{RELEVANT ASPECTS: TEHNOLOGICAL, REGULATORY, ECONOMIC, AS WELL AS ONLINE AUDIT ARCHITECTURE IMPLEMENTATION}

An online audit environment implementation implies:

- collaboration between institutions holding databases;

- development of additional applications that take over other non-informatized procedures;

- capitalization of initiatives and experiences to ensure knowledge and hardware or software platforms compatibility;

- in Romania, as part of the efforts to develop egovernment services, the Ministry of Communications and Information Technology has established a common framework for interconnection and integration of applications and data (standards, policies). The main advantage of this approach is that it allows compatibility of structural components by aligning them to standards, ensuring thus increasing interoperability and integration.

Given that currently there is not a national hardware, software and communication infrastructure in place, to enable an online audit platform implementation, existing applications are limited to processing information from heterogeneous data sources in a traditional manner, being 
expected that the online audit architecture to be functional in an e-government platform. Currently, applications interoperability is provided only partly online.

The main premise of this approach is technologically feasible: financial and accounting information is generally recorded and stored on an electronic support (or alternative, but accessible environment).

From technological perspective, there are many factors to be considered in designing applications in this category:

- Variety of obsolete systems and their poor communication facilities;

- Risks induced by security exposure for online access;

- The fact that some applications can not be audited online.

Changing the audit approach by targeting it to use information technology mainly consisted in: expanding electronic transmission of information, globalization of information exchange, popularization of information technology applications.

Issues related to the implementation of an online audit platform are very wide, containing aspects of various fields: legal, financial, technological, human resources and others.

Creating an IT based audit platform involves: designing a network architecture, applications fund creation, the existence of an adequate security system, ensuring interoperability of applications, provision of appropriate equipment, alignment with industry standards, personnel training. Computerized audit quality decisively depends on the quality of human resources, which represent a key factor in promoting the new computer-based work style. Creating a favorable environment for the implementation of information technology auditing is a major audit objective. Training of auditors in IT audit dedicated programs is a necessity, as the rapid evolution occurs in this field.

\section{INFORMATION COLLECTION AND PROCESSING WITHIN AN ONLINE AUDIT PLATFORM}

Within the audit online platforms, using information technology to collect and process data occupies a very wide range and gives a high efficiency of the audit process. Using electronic data, from various sources, requires specialized hardware and software infrastructure, able to ensure the provision of information of the audited entities and their collection by the auditor, aiming the processing according to the audit objectives.

Such an approach is marked and affected by a series of disadvantages:

(a) Data check is difficult because you can not make objective judgment based only on data as they are, validation is required by other information that reflects internal coherence of the audited entity. In certain situations requires written confirmation from the audited entity.

(b) Gradul de corelare a datelor este scăzut, având în vedere faptul că entităţile furnizează informaţiile prin intermediul unor aplicaţii diverse, unele învechite, dezvoltate independent, care nu deţin proceduri standardizate şi nu se bazează pe un sistem unic de codificare. In consecinţă, cu toate că datele provin de la aceeaşi entitate, nu se pot face în mod direct comparaţii sau alte prelucrări asupra lor.

(c) Data correlation is low, given that entities providing information through different applications, some obsolete, developed independently, not standardized and not based on a unique coding system. Consequently, although data comes from the same entity, they can not be compared or processed.

(d) The amount of available data is limited, because some institutions only partly use information technology, thus reducing substantially the sources of information for IT audits.

Using the audit information from different, heterogeneous data sources, yet allows the organization to aggregate and reuse them according to the audit purpose, if it is done by a highly qualified expert. General analysis, cross comparisons of different data collection can be performed, which constitute a vast informational content for the auditor. The quality of a computer based analysis on a variety of information is reflected in the number and quality of findings, in efficiency increase and effects on audit performance.

\section{DATABASE AUDIT: A GENERIC APPLICATION}

Given that currently there is not a national hardware, software and communication infrastructure in place, to enable an online audit platform implementation, existing applications are limited to processing information from heterogeneous data sources in a traditional manner, being expected that the online audit architecture to be functional in an e-government platform. In this context, because the application only partly ensures interoperability online, we will describe a solution to implement an auditing procedure through heterogeneous databases:

(1) Audit of records stored in a database provided by the audited entity

Audit's purpose is to highlight the absence or presence of incorrect records of transactions. This is achieved by controlling data in terms of criteria imposed by the audit objectives and auditing specific.

(2) Audit records stored in databases from heterogeneous sources

Audit's purpose is to highlight the absence or presence of inconsistent records of transactions. This is achieved by controlling the correspondence between records from different sources, transferred / converted into a common search space.

Building common area of search from heterogeneous data sources, allows:

(a) establishing a common reference on entries from provided files;

(b) comparative analysis of data collections from different perspectives and in terms of multiple criteria, in most cases through an iterative process of records, facilitated by the fact that they have a common key by comparison. 
The auditing process implies a series of specific parts such as:

(a) Search area requires:

- extraction of key identifiers lists of records in databases that are subject to processing;

- building the search space using previously built lists;

- finding lists intersection: identifying key finding from a database which is found in the list of keys from a correspondent database subject to processing (common identification keys);

- finding the list of inconsistencies between records with corresponding keys;

- define an audit context with specific risk criteria (certain factors or situations that impact the audited entity)

b) Obtaining partial results is achieved by providing junction of lists that provide search space in terms of common identification keys.

(c) Analysis and interpretation of results requires the analysis process (iterations of the identification keys of interest), based on criteria imposed by the audit application. This yields a set of records that can be compared by human interpretation to be detected irregularities or inconsistencies.

(d) Processing of discrepancies is done by analyzing search space and interpretation of results to identify differences or inconsistencies between records.

(e) Conduct investigations by consulting additional databases.

d) Completion of investigations

Following investigations made on the databases all information are obtained (including historical ones) to make a judgment on the operations. Completion of investigation focuses on: analyzing, correlating and interpreting the findings, defining the conclusions and recommendations.

Implementation of online audit involves extension of information technology in all areas of audit, in audit institutions at all levels.

\section{CONCLUSION}

Worldwide, the concept of audit evolves to continuous audit and online audit. The audit began to move from practitioners focus to a research topic, being increasing interest from the educational field. Also, audit subject evolved to IT audit.

As a result of rising expectations of users as information to be available in real time and that new technologies allow such reporting (not necessarily financial) there will be more and more implementations of the continuous auditing concept. If previously IT played an ambiguous role in a business, balancing between business process facilitation or definition, depending on how well it was integrated within the goals and strategies of the company, now we can definitely say that IT is part of any organization. It is obvious that computer systems are essential in business communications, accounting, manufacturing, supply chain management, etc. IT is as important as the earnings of a business success as well as its losses.

Today, most organizations are now dependent on technology, mainly of associated risks, which translates into the need for companies not only to control the IT infrastructure, but also to prove this as an independent IT audit report.

Audit, whatever form it takes, refers to the evaluation of the implemented management controls to minimize risks. Thus, IT audit will consider information technology management, meaning information resources and their organization (the network). "State of the art" in IT management is moving towards automation.

An analysis of automated IT audit methods currently used, they performed tests of compliance with a benchmark model considered effective.

In information audit, standardization of control objectives pursued in the business allows their formalization.

Finally, we believe that the evolution of present technology allows adoption them towards areas previously considered uniquely human, such as carrying out audits.

\section{REFERENCES}

[1] Buraga S. C., (2004) Semantic web, fundamente şi aplicatii. Matrix ROM, Bucureşti

[2] Borst W. N. (1997), Construction of Engineering Ontologies for knowledge sharing and reuse. $\mathrm{PhD}$ hesis, University of Twente, Enschede

[3] Coderre D.(2005), Global technology audit guide, continuous auditing: Implications for assurance, monitoring and risk assessment. The Institute of Internal Auditors

[4] Danescu, T., (2007) Audit financiar, convergen_e între teorie si practica, Editura Irecson, Bucuresti

[5] Dobroteanu, L. \& Dobroteanu, C., (2002), Audit, concepte si practici, Editura Economica, Bucuresti

[6] Gallegos F. \& Sandra S. (2008). Information technology control and audit, third edition. Auerbach Publications

[7] Ghiţă M.; Nicolau C.; Zaharica F. I.; Peres I.; Bunget O. C. \& Peres C. E.,(2009) Guvernanţa corporativă şi auditul intern. Editura Mirton

[8] Hansen, J. V. \& W. F. Messier Jr., (1987), Expert Systems in Auditing, Auditing: A Journal of of Theory and Practice

[9] Johnson G.L. (2006), New standard guides internal and supplier audits, Quality Progress march vol.39, issue 3, p. 25-30

[10] Kelly, K., G. Ribar \& J. Willingham, (1988) Interim Report on the Development of an Expert System for the Auditor's Loan Loss Evaluation, Artificial Intelligence in Accounting and Auditing, Miklos A. Vasarhelyi, ed. (Markus Wiener Publishing Company)

[11] Ming C. (2011), The perveived impact of quality audit on the work of academics, Higher Education Research \& Development vol. 30 , issue 2

[12] Mircea B. \& Marcel G. (2001) Fundamentele auditului, Editura Didactică si Pedagogică, Bucureşti

[13] Moeller Rober (2010), It audit, control and security. John Wiley and Sons Inc.

[14] Munteanu A.(2001), Auditul sistemelor informationale contabile cadru general. Editura Polirom

[15] Nastase P., Stanciu V. \& Ali E.(2007), Auditul şi controlul sistemelor informationale. Editura Economica, Bucuresti

[16] Oprean D.(2002), Audit. Presa Universitara Clujeana

[17] Oprean, I.; Popa, I.E., \& Lenghel, R., D., (2007), Procedurile auditului si ale controlului financiar, Editura Risoprint, Cluj Napoca;

[18] Pathak, J., (2005), Auditul Tehnologiei infomatiei: o adaptare continua, Editura Springer-Verlag,Berlin, Germania

[19] Rogers R., (2008), Nessus network auditing, second edition. Syngress Publishing, 2 edition

[20] Tiron Tudor, A., et al., (2009) Fundamentele auditului financiar, Editura Accent, Cluj Napoca 